Pacific Journal of Mathematics

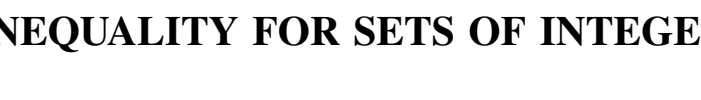




\title{
AN INEQUALITY FOR SETS OF INTEGERS
}

\author{
Peter Scherk
}

Small italics denote nonnegative integers. Let $A=\{a\}, B=\{b\}, \cdots$ be sets of such integers. Define $A+B=\{a+b\}$ and put

$$
A(n)=\sum_{0<a \leq n} 1 \quad \text { and } \quad A(m, n)=\sum_{m<a \leq n} 1
$$

Thus

$$
A(n)=A(0, n) \text { and } A(m, n)=A(n)-A(m) \text { if } m \leq n .
$$

The following estimate is well known:

LEMmA. If $m<k<n, n \notin A+B$, then

$$
k-m \geq A(n-k-1, n-m-1)+B(m, k) .
$$

Proof. If $b=n-a$, then $n=a+b \in A+B$. Hence the $A(n-k-1, n-m-1)$ numbers $n-a$ with $m<n-a \leq k$ and the $B(m, k)$ numbers $b$ satisfying $m<b \leq k$ are mutually distinct. The right hand term of (1) gives their total number. It is not greater than the number $k-m$ of all the integers $z$ with $m<z \leq k$.

The most important result on $A+B$ is due to Mann [2]: Let $n \notin C=A+B$. Then there exists an $m$ satisfying $0 \leq m<n$ and $n-m \notin C$ such that

$$
C(m, n) \geq A(n-m-1)+B(n-m-1) .
$$

I wish to prove a less well known inequality which is implicitly contained in [4] and in a paper by Mann [3]. The present proof uses an idea by Besicovitch and is rather simpler than Mann's method [ cf. 1].

Theorem 1. Let

$$
x \in A
$$

$$
(x=0,1,2, \cdots, h ; h \geq 0),
$$

Received December 29, 1953.

Pacific J. Math. 5 (1955), 585- 587 


$$
0 \in B \quad \text { or } \quad 1 \in B \text {, }
$$$$
A+B \subset C, n \notin C .
$$

Finally let

$$
C(n)<A(n-1)+B(n) .
$$

Then there is an $m$ satisfying

$$
m \notin C, \quad 0<m<n-h-1
$$

such that

$$
C(m, n) \geq A(n-m-1)+B(m, n) .
$$

We note that $(7)$ is trivial but useless without the second half of (6). Obviously, (2) - (4) imply $m>h$ if $0 \in B$ and $m>h+1$ if $1 \in B$.

Proof. Instead of (3), we merely use the weaker assumption that $B$ is not empty. Let $b_{0}$ denote the largest $b \leq n$. Thus $B\left(b_{0}, n\right)=0$. Since $C$ contains the integers $b_{0}+a$ with $0<a \leq n-b_{0}$, we have

$$
C\left(b_{0}, n\right) \geq A\left(n-b_{0}\right) \geq A\left(n-b_{0}-1\right)=A\left(n-b_{0}-1\right)+B\left(b_{0}, n\right) .
$$

From (5) and (8), $b_{0}>0$. By (2), the numbers $b_{0}, b_{0}+1, \cdots, b_{0}+h$ lie in $A+B \subset C$. Hence $n \notin C$ implies $b_{0} \leq n-h-1$. Thus

$$
0<b_{0} \leq n-h-1
$$

By (2), $b_{0} \in C$. Let $m$ denote the greatest $z<b_{0}$ with $z \notin C$. If no such $z$ exists, put $m=0$. Applying (1) with $k=b_{0}$, we obtain

$$
C\left(m, b_{0}\right)=b_{0}-m \geq A\left(n-b_{0}-1, n-m-1\right)+B\left(m, b_{0}\right) .
$$

Adding (8) and (10), we obtain

$$
\begin{aligned}
C\left(m, b_{0}\right)+C\left(b_{0}, n\right) \geq A\left(n-b_{0}-1\right) & +A\left(n-b_{0}-1, n-m-1\right) \\
& +B\left(m, b_{0}\right)+B\left(b_{0}, n\right),
\end{aligned}
$$

that is (7). By (7) and (5), $m>0$. Hence $m \notin C$. Finally (9) and $m<b_{0}$ imply $m<n-h-1$.

The following corollary of Theorem 1 was proved in a different way by Mann. 
THE OREM 2. Suppose the sets $A, B, C$ satisfy the assumptions (2)-(4). Let $0<\alpha_{1}<1$ and

$$
A(x) \geq \alpha_{1}(x+1) \quad(x=h+1, h+2, \cdots, n) .
$$

Then

$$
C(n) \geq \alpha_{1} n+B(n)
$$

Proof. By (2), $0 \in A$. Furthermore, (11) and (2) imply $1 \in A$. Hence, (3) implies $1 \in C$. Thus our theorem is true for $n=1$. Suppose it is proved up to $n-1 \geq 1$.

If $C(n) \geq A(n-1)+B(n)$, then (11) with $x=n-1$ yields (12). Thus we may assume (5). Choose $m$ according to Theorem 1. By (6), $n-m-1 \geq h+1$. Hence, by (7), (11), and our induction assumption

$$
\begin{aligned}
C(n) & \geq C(m)+A(n-m-1)+B(m, n) \\
& \geq C(m)+\alpha_{1}(n-m)+B(m, n) \\
& \geq \alpha_{1} m+B(m)+\alpha_{1}(n-m)+B(m, n)=\alpha_{1} n+B(n) .
\end{aligned}
$$

The case $h=0$ of Theorem 2 is due to Besicovitch [1]. Obviously, this theorem can be extended to the case that $0 \notin B, B(n)>0$.

A recent result by Stalley also follows readily from Theorem 1.

\section{REFERENCES}

1. A.S. Besicovitch, On the density of the sum of two sequences of integers, J. London Math. Soc. 10 (1935), 246-248.

2. H. B. Mann, A proof of the fundamental theorem on the density of sums of sets of positive integers, Ann. of Math. 43 (1942), 523-527.

3. On the number of integers in the sum of two sets of positive integers, Pacific J. Math. 1 (1951), 249-253.

4. P. Scherk, Bemerkungen zu einer Note von Besicovitch, J. London Math. Soc. 14 (1939), $185-192$.

5. R.D. Stalley, A modified Schnirelmann density, Pacific J. Math. 5 (1955), 119-124.

\section{UNIVERSITY OF SASKATCHEWAN}





\section{PACIFIC JOURNAL OF MATHEMATICS}

\section{EDITORS}

\section{H.L. ROY DEN}

Stanford University

Stanford, California

E. HEWITT

University of Washington

Seattle 5, Washington

\section{R. P. DILWORTH}

California Institute of Technology

Pasadena 4, California

* Alfred Horn

University of California

Los Angeles 24, California

\section{ASSOCIATE EDITORS}

\begin{abstract}
H. BUSEMANN
HERBERT FEDERER

MARSHALL HALL
\end{abstract}

\section{P.R. HALMOS}

HEINZ HOPF

ALFRED HORN
R.D. JAMES

BØRGE JESSEN

PAUL LÉVY
GEORGE PÓLYA

J.J. STOKER

KOSAKU YOSIDA
UNIVERSITY OF BRITISH COLUMBIA CALIFORNIA INSTITUTE OF TECHNOLOGY UNIVERSITY OF CALIFORNIA, BER KELEY UNIVERSITY OF CALIFORNIA, DAVIS UNIVERSITY OF CALIFORNIA, LOS ANGELES UNIVERSITY OF CALIFORNIA, SANTA BARBARA MONTANA STATE UNIVERSITY

UNIVERSITY OF NEVADA

OREGON STATE COLLEGE

UNIVERSITY OF OREGON
UNIVERSITY OF SOUTHERN CALIFORNIA STANFORD UNIVERSITY UNIVERSITY OF UTAH WASHINGTON STATE COLLEGE UNIVERSITY OF WASHINGTON

AMERICAN MATHEMATICAL SOCIETY HUGHES AIRCRAFT COMPANY SHELL DEVELOPMENT COMPANY

Mathematical papers intended for publication in the Pacific Journal of Mathematics should be typewritten (double spaced), and the author should keep a complete copy. Manuscripts may be sent to any of the editors. Manuscripts intended for the outgoing editors should be sent to their successors. All other communications to the editors should be addressed to the managing editor, Alfred Horn, at the University of California Los Angeles 24, California.

50 reprints of each article are furnished free of charge; additional copies may be obtained at cost in multiples of 50 .

The Pacific Journal of Mathematics is published quarterly, in March, June, September, and December. The price per volume (4 numbers) is $\$ 12.00$; single issues, $\$ 3.50$; back numbers (Volumes $1,2,3$ ) are available at $\$ 2.50$ per copy. Special price to individual faculty members of supporting institutions and to individual members of the American Mathematical Society: $\$ 4.00$ per volume; single issues, $\$ 1.25$.

Subscriptions, orders for back numbers, and changes of address should be sent to the publishers, University of California Press, Berkeley 4, California.

Printed at Ann Arbor, Michigan. Entered as second class matter at the Post Office, Berkeley, California.

* During the absence of E.G. Straus.

UNIVERSITY OF CALIFORNIA PRESS - BERKELEY AND LOS ANGELES 


\section{Pacific Journal of Mathematics}

\section{Vol. 5, No. $4 \quad$ December, 1955}

Richard Horace Battin, Note on the "Evaluation of an integral occurring in servomechanism theory" ............................. 481

Frank Herbert Brownell, III, An extension of Weyl's asymptotic law for eigenvalues................................. 483

Wilbur Eugene Deskins, On the homomorphisms of an algebra onto Frobenius algebras .................................. 501

James Michael Gardner Fell, The measure ring for a cube of arbitrary dimension ....................................... 513

Harley M. Flanders, The norm function of an algebraic field extension. II ............................................ 519

Dieter Gaier, On the change of index for summable series ............ 529

Marshall Hall and Lowell J. Paige, Complete mappings of finite groups . . . . 541

Moses Richardson, Relativization and extension of solutions of irreflexive relations..................................... 551

Peter Scherk, An inequality for sets of integers .................. 585

W. R. Scott, On infinite groups ........................... 589

A. Seidenberg, On homogeneous linear differential equations with arbitrary constant coefficients ......................................... 599

Victor Lenard Shapiro, Cantor-type uniqueness of multiple trigonometric integrals...

Leonard Tornheim, Minimal basis and inessential discriminant divisors for a cubic field...

Helmut Wielandt, On eigenvalues of sums of normal matrices ... 